\title{
REFLEKSI KRITIS IDEOLOGI PENDIDIKAN KONSERVATISME DAN LIBRALISME MENUJU PARADIGMA BARU PENDIDIKAN
}

\author{
I Ketut Wisarja1 ${ }^{*}$, , I Ketut Sudarsana ${ }^{2}$ \\ ${ }^{1}$ Institut Hindu Dharma Negeri Denpasar \\ 2 Institut Hindu Dharma Negeri Denpasar
}

\section{Abstrak}

The general assumption is that education as a means of acquiring knowledge and knowledge is not indisputable, but the notion that education is available only in the formalist environment is naïve, as it excludes other possibilities where education is also derived from non-formal (andragogic) educational models such as; education pasraman, ashram, pesantren, and so forth. Conservative paradigm with all its attributes, such as; educational fundalism, educational intellectualism, and educational conservatism, basically more towards the attainment of a quo-vadis form of education and harmonization, without any criticism of all pre-existing conditions and post-conditions of knowledge and awareness. This concept is basically not too far from the mere 'establishment' view of educational practices (prison education / shackles), which ultimately leads to the assumption / stigma that educational intellectualism can not be separated from the subject of interest. Then comes the libral paradigm with all its attributes that assume the main purpose of education is to preserve and improve the existing social order, by educating based on existing social reality. The culmination is anarchism of education which tends to a form of conception of the idea of how to rationalize education, eventually this paradigm tends to reject firmly existing order and construct into a more humane and moral education.
\end{abstract}

\author{
Keywords: \\ Educational Ideology, \\ Education \\ Conservatism, \\ Libralism of Education, \\ Education Criticism, \\ and Autocritics.
}

\section{PENDAHULUAN}

Pendidikan sebagai salah satu alternatif normatif untuk memperoleh sebuah pengetahuan tidaklah terbantahkan, sedangkan disisi lain definisi pendidikan menurut sebagian ahli patut dijadikan sebagai bahan perdebatan. Pendidikan sendiri tidak terlepas dari berbagai macam kritik sebagai bagian dari eksistensi perkembangan pendidikan. Mencoba memahami sebuah konsepsi tentang pendidikan, sering kali menjebak seseorang ke alur pendidikan secara pragmatis-fungsionalis, dimana pendidikan sematamata hanya dilihat dari sudut pandang sejauh mana pendidikan itu bernilai guna. Selama ini kita terjebak pada fungsi pendidikan sebagai pemenuhan kebutuhan kerja, bukannya sebagai material dasar untuk memperoleh pengetahuan yang sesungguhnya.

Meminjam pendapat Habermas (1972) sebagaimana dikutif O'neil (2002: XV-XVI) mengenai makna dari pengetahuan. Ada tiga dasar pokok yang dapat dipahami, yakni; Pertama, pengetahuan sebagai instrument knowledge, artinya pengetahuan dijadikan sebagai tempat untuk mengontrol, memprediksi, memanipulasi, dan mengeksploitasi terhadap objeknya. Kedua, pengetahuan sebagai hermeneutik knowledge, artinya pengetahuan hanya dimaknai sebagai tempat pemahaman, dan Ketiga, pengetahuan sebagai critical knowledge, artinya pengetahuan sebagai katalis kritis terhadap 'the dominant ideology' kearah transformasi sosial.

Dalam perspektif kritis, pendidikan hendaknya ditempatkan sebagai penganalisis dan pengidentifikasi kritis serta bebas menuju transformasi sosial. Keterpurukan kita sebagai pengkonsumsi pengetahuan lewat pendidikan seringkali tanpa sadar terikat dengan 'sistem' dan tidak dapat terlepas dari persoalan kepentingan atau dengan kata lain dominant ideology melalui pendidikan. Tujuan utama dari pendidikan itu sendiri adalah sebagai bagian dari pembentukan kesadaran yang terapresiasi melalui pengetahuan. Meminjam definisi kesadaran dari Freire (1999: 24) yang membagi kesadaran manusia menjadi tiga bagian yaitu; kesadaran magis (magical consciousness), kesadaran naif (naival consciousness), kesadaran kritis (critical consciousness). Kesadaran magis lebih diartikan sebagai tingkat 
kesadaran yang tidak mempunyai daya analisis atas sebuah realitas, sedangkan kesadaran naif lebih bermakna 'aspek manusiawi' sebagai akar penyebab masalah di masyarakat. Untuk kesadaran yang ketiga lebih melihat aspek sistem dan struktur sebagai sumber masalah.

Batasan nilai dan makna pendidikan itu sendiri seringkali dimaknai secara abstrak sehingga membentuk sebuah opini publik, bahwa pendidikan haruslah 'legal formal' dan bersifat 'netral'. Mungkin kita seharusnya secara bersama-sama memperbincangkan apa makna terdalam dari pendidikan itu sendiri? belum lagi kita berbicara mengenai siapa yang berhak memperolehnya? dan ukuran apa yang hendak dipakai dalam penggolongannya?.

Berbicara mengenai 'batasan' pendidikan, maka kita akan memasuki wilayah ideologi apa yang dipakai pendidikan dengan berbagai nilai kajian (subject matter) yang terangkum di dalamnya. Pembicaraan tersebut akan lebih jelas dengan menampilkan berbagai contoh ideologi pendidikan yang berkembang dan kita pakai selama ini. Sekali lagi, kritik terhadap muatan-muatan ideologi pendidikan yang dimaksud tentu saja wajib diadakan secara kritis dan bebas sebagai bahan perbandingan.

Ideologi yang dimaksud terbagi dalam ideologi pendidikan yang bersifat konservatif, dengan beberapa paradigma yang termuat di dalamnya seperti fundamentalis, intelektualisme, dan konservatif. Sedangkan ideologi yang kedua yang bersifat liberal, dengan beberapa paradigma yang ada di dalamnya seperti liberal, liberalsionis, dan anarkis. Penjabaran paradigma yang ditelurkan dari dua ideologi yang dimaksud tentu saja mempunyai daya refleksi yang begitu kuat pengaruhnya bagi permasalahan pendidikan dewasa ini. Terlepas apakah memakai, menganut, dan menyebarkan ideologi yang dimaksud, ada persoalan yang jauh lebih esensial yang perlu kita sepakati sebagai bahan perdebatan lebih lanjut. Rasionalisasi pendidikan dari berbagai ideologi yang ditawarkan merupakan kemutlakan yang wajib dikritisi secara bebas dengan mencoba menawarkan wacana baru yang sifatnya bernilai lebih kearah pendekatan realisasi pengembalian 'roh' pendidikan yang sesungguhnya.

Wacana akan rasionalisasi pendidikan pada dasarnya sudah mulai nampak pada era 70-an, tokoh seperti Ivan Illich dan Paulo Freire yang mencoba mengajukan berbagai argumen menarik seputar pendidikan dan hakikatnya, serta permasalahan pendidikan dengan berbagai 'muatan' yang terdapat di dalamnya termasuk juga pembicaraan mengenai aspek yang mendasari pendidikan itu dengan berbagai macam kepentingannya. Terlepas dari tawaran tersebut, sudah saatnya kita mengalami pencerahan tentang hakikat pendidikan sesungguhnya, bukannya kita hanya berkutat pada permasalahan 'objektivisasi', dimana kedudukan kita sebagai 'pengkonsumsi' ilmu dan pengetahuan melalui pendidikan akan terus berada dalam jalur sebatas sebagai objek tanpa ada nilai tawar untuk menjadi subjek dari pendidikan itu sendiri.

Demikian sebuah pendidikan yang seharusnya ditempatkan pada 'jalur' pendidikan sesungguhnya yang pada dasarnya tak terlepas dengan berbagai permasalahan yang memudarkan nilai dan esensi dari pendidikan itu sendiri. Pendidikan yang seharusnya sebagai upaya untuk mencerdaskan peradaban manusia, bukannya sebagai ajang 'monopoli' dalam rangka membentuk sebuah peradaban yang sifatnya terbentuk dengan berbagai tujuan tertentu pula. Pendidikan yang dianggap mulia dan mengandung kebajikan ternyata mengalami sebuah krisis kepercayaan atas ketidak-mampuan pendidikan sebagai penyuplai ilmu dan pengetahuan dalam menghadapi segala realitas dan tantangan zaman, oleh karena itu tulisan singkat ini sebagai upaya rekonstruksi permasalahan tersebut.

\section{ANALISIS DAN PEMBAHASAN}

Asumsi secara umum mengenai makna dari pendidikan sebagai sarana untuk memperoleh ilmu dan pengetahuan tidaklah dapat dipersalahkan sepenuhnya. Konsepsi mengenai semua itu sudah merupakan ketentuan umum yang telah kita sepakati bersama. Lain halnya dengan sebagian orang tertentu yang mempunyai asumsi sendiri tentang makna terdalam dari sebuah pendidikan, dimana pendidikan lebih diartikan sebagai 'instrument' untuk mendapatkan ilmu dan pengetahuan yang sesungguhnya. Kalaupun ada pendapat bahwa pendidikan hanya didapat dari lingkungan formalis misalnya, sekolah, perguruan tinggi, pesantren, dan sebagainya dengan asumsi bahwa hanya dari situlah tempat ilmu dan pengetahuan diperoleh (paedagogis), dan menutup kemungkinan lain tanpa melihat aspek diluar itu semua, dimana pendidikan yang diajarkan dengan model pendidikan non formal (andragogis).

Terlepas dari pembedaan cara memperoleh ilmu dan pengetahuan yang didapat, ada baiknya kita sendiri secara sadar melakukan kritik atas 'muatan' pendidikan itu sendiri dari konsepsi selama ini. Pendidikan dianggap sakral, penuh kebajikan tersebut ternyata tidak terlepas dari berbagai kepentingan yang pada dasarnya menindas (Freire, 1973: 30). Kritik tersebut justru semakin memperkaya pemaknaan pendidikan itu sendiri, sehingga diharapkan nantinya menghasilkan pemahaman-pemahaman baru yang lebih tepat mengenai pendidikan dan permasalahannya. Selama ini 'konsumen' pendidikan tanpa sadar 
terjebak dan mengikuti alur yang tidak jauh dari persoalan kapitalisme, kalaupun ada yang menerjemahkan bahwa pendidikan itu bersifat netral dari unsur-unsur kapitalisme gaya baru, tentu saja pendapat demikian sesungguhnya tidak memahami 'muatan' serta 'ideologi pendidikan' apa yang sudah terdistribusi ke dalam ilmu dan pengetahuan yang telah terkonsumsi. Lebih lanjut dari arah pendidikan tersebut ternyata dapat disimpulkan bahwa fungsi utama pendidikan tak lain hanyalah sebagai gudang mencari tenaga kerja bagi industri yang telah tersedia. Seolah-olah hasil atau produk dari pendidikan selalu mengarah ke arah marginalisasi nilai ilmu dan pengetahuan itu sendiri. Terdapat semacam gagasan untuk lebih mengarahkan bahwa para pendidik dengan yang dididik terarahkan ke dalam sebuah fenomena kepentingan, khususnya sebagai bahan utama pengisi industrialisasi dan tak lebih dari itu. Terlepas dari apakah kita menyadari atau tidak hakikat dari ideologi apa yang dipakai dalam pendidikan itu sendiri.

Dalam terminilogi O'neil (2002: XXXI) paradigma pendidikan dewasa ini terbagi dalam tiga bagian. Pertama; Paradigma Konservatif, dimana stratifikasi sosial dalam masyarakat merupakan suatu hukum yang alami, sebagai sebuah takdir ilahi. Dasar keyakinan yang dibentuk adalah bahwa masyarakat pada dasarnya tidak merencanakan perubahan atau mempengaruhi perubahan sosial. Kedua; Paradigma Liberal, dimana golongan ini beranggapan tidak ada keterkaitan antara persoalan politik dengan ekonomi masyarakat. Kedua hal tersebut merupakan salah satu dari sekian petunjuk yang dapat dikaji keberadaannya dalam memahami dan menentukan arah pencarian eksistensi pendidikan di Indonesia. Ketiga; adalah Paradigma Kritis yang nantinya sebagai tolok ukur pembahasan dalam penulisan ini, dimana paradigma yang terakhir ini lebih pada upaya rekonstruksi dari dua paradigma di atas dengan berbagai persoalan yang dimunculkannya.

Berbicara mengenai dunia pendidikan, maka kita berbicara tentang proses kajian ilmiah yang rasional atas sebuah ilmu dan pengetahuan. Pendidikan di Indonesia pada khususnya mengalami sebuah degradasi acuan atau pegangan pada konteks pengajaran dan pembelajaran, dimana tuntutan menjadikan murid sebagai subjek hampir-hampir tidak diberikan ruang gerak oleh kurikulum yang dijalankan. Persoalanya adalah pada dasarnya kurikulum yang sedang dijalankan dan bahkan sampai sekarang ini tak lain hasil adopsi dari dua paradigma di atas (paradigma konservatif dan liberal). Ironisnya Indonesia tidak cukup mampu mengorganisir kedua paradigma tersebut sehingga ketidakjelasan begitu nampak disana. Berkaitan dengan permasalahan pendidikan di Indonesia sudah sepatutnya pendidikan bukannya dijadikan objek dari ilmu dan pengetahuan itu sendiri. Bicara mengenai perkembangan pendidikan di Indonesia berkaitan dengan berbagai permasalahan yang melingkupinya, dimana pada dasarnya bentukan pola lama yang mewarisi tradisi pengajaran 'sungkem' (sembah) yang berarti tunduk pada yang lebih tua. Istilah ini mulanya untuk memberikan petunjuk tegas antara bangsawan disatu sisi dihadapkan pada rakyat jelata, konsekuensinya merambah pada iklim kelas dalam konteksasi pembelajaran taman siswa, menjadi semacam taruhan yang paling dapat dicerna sebagai pangkal untuk penyelidikan lebih jauh polarisasi struktur pendidikan gaya kolonial, utamanya orang Jawa. Taman Siswa adalah struktur pendidikan yang berbasis pada kontrol mekanik yang sedemikian rupa menyusun sebuah sistem ala kartu domino. Pasalnya, ketika Taman Siswa yang merepresentasikan tradisi pergaulan belajar Jawa harus masuk dan merambah dimensi kesukuan yang lain. Persoalannya adalah mengenai orientasi pembelajaran dan perbaikan iklim yang sedemikian berbeda, seperti; karakteristik, pola laku, sistem nilai, dan sebagainya, namun yang jelas dari kesemuanya itu merindukan sesuatu hal yang sama, yakni perbaikan masa depan bangsa dan meraih kemerdekaan pada saat itu.

Inti sari perimbangan yang sama agaknya sedikit terbuka untuk memberi keterangan bahwa sementara ini pola pendidikan di Indonesia masih berlaku sistem konservatif. Akan tetapi tidak mudah untuk menyatakannya dalam bentuk hitam putih. Banyak dijumpai latar belakang pendidikan kolonial yang terwadahi dalam kolese-kolese atau pondok pesantren (Pesantren sama halnya dengan Pasraman yang karakteristiknya hampir sama dengan daerah asalnya). Dua institusi terakhir berkedudukan sama yang merentangkan sayap konservatisme pendidikan.

Jika kita mencoba mencari titik singgung dari kemajemukan dan ragam konservatisme pendidikan dalam berbagai wajah ini, ada baiknya kita sedikit memberikan tempat untuk deliberalisasi pendidikan yang tampaknya harus singgah sebentar dalam menyumbangkan pengaruhnya bagi perkembangan pendidikan saat ini. Gelagat liberalisme pendidikan terbawa juga ketika Soekarno membuka lebar-lebar masuknya wacana asing pada tahun 60-an dengan mengirimkan berbagai sarjana untuk menimba ilmu di luar negeri. Terbatasnya tempat ruang lingkupnya seolah menutup kesempatan untuk membaca secara luas bahwa sebenarnya era tersebut menandai lahirnya intelektual baru yang tersebar di beberapa universitas terkemuka di Indonesia.

Sekarang yang kita perlukan adalah sebuah bentuk kritis yang tertera pada iklan-iklan pendidikan tersebut. Pada garis dan kebijakan tertentu sebagai refleksi ketidakberhasilan pendidikan konservatif dan liberalisasi pendidikan yang selalu berbenturan karena menutup rapat-rapat makna kritisisme di 
dalamnya. Perolehan hasil dari perseteruan terselubung yang kerapkali dilakukan keduanya masih saja terbukti berputar pada aspek pengkondisian internal. Rekonsolidasi yang tak pernah mempunyai aspek keluar yang menjanjikan perubahan mendasar, setidaknya pada kualitas pendidikan. Daya jual yang diukur dengan parameter keberhasilan mendirikan peradaban yang benar-benar merasa ada di dalamnya ketertarikan, substansi khusus yang secara sadar menerjemahkan realitas dan menggerakkan sistem yang mampu menentukan posisi diantara kelompoknya.

Indonesia benar-benar di persimpangan dua ideologi pendidikan besar. Konservatisme di satu sisi, menghasilkan watak dan etos yang lebih terfokus pada pengaplikasian nilai-nilai kelompoknya. Serta liberalisme di sisi lain yang mengembangkan peranan individu yang mampu berderet ukur dengan perkembangan mutlak dari keberadaan sistem besar dunia yang terus bergerak fluktuatif.

Pilihan yang menuntut kita berpikir dalam kerangka relatif dan menjauhi konsep spekulatif asal jadi yang justru memudarkan proses pencarian eksistensi pendidikan. Lebih penting perbendaharaan kosakata ideologi pendidikan Indonesia memainkan kontinuitas secara historis sehingga membentuk karakter pendidikan yang aktif serta dinamis. Memperkaya pemahaman terhadap kemajuan yang telah ada dalam dimensi lain dari rangkaian struktur pendidikan. Jadi unsur penting yang patut diduga akan menyebabkan dan anggaplah sebuah praduga samar bahwa akan ada pluralisme yang lebih bernuansa obyektif-logis yang terinspirasi dari sinkretisme ideologi pendidikan yang telah ada ditambah muatan baru, kritisisme.

\section{Memaknai Paradigma Konservatif}

\section{a. Fundamentalisme Pendidikan}

Unsur utama dari penerapan model pendidikan seperti ini lebih melihat ke aspek konservatisme politik yang pada dasarnya anti-intelektualisme, dalam arti; mereka ingin meminimalkan pertimbanganpertimbangan filosofis (intelektual) serta cenderung untuk mendasarkan diri mereka pada penerimaan yang relatif tanpa kritik terhadap kebenaran yang diwahyukan atau ketaatan atas konsensus sosial yang sudah mapan. Dalam paradigma fundamentalis sendiri terdapat dua sudut pandang yang berbeda penerapan atas pendidikannya. Pertama, fundamentalis pendidikan religius, dimana keteguhan hati (komitmen) sebagai ukuran ketaatan didasarkan pada Al-kitab (baca kitab Suci). Kedua, fundamentalis pendidikan sekuler, berciri pengembangan komitmen secara 'akal sehat' dengan hasil generalisasi melalui kesepakatan umum dan diterima. Paradigma fundamentalis sendiri pada dasarnya lebih kearah pencapaian bentuk pendidikan yang bersifat quo-vadis dan lebih kearah harmonisasi dengan apa yang sudah ada, tanpa ada tahapan pengkritisan dari segenap pra-kondisi maupun pasca-kondisi pengetahuan dan kesadaran yang sudah ada.

b. Intelektualisme Pendidikan

Ciri utama dari tipe pendidikan seperti ini lebih kearah sebuah bentuk konservatif politik yang didasarkan pada sistem pemikiran filosofis yang lebih menempatkan intelektual individu dalam 'posisinya' mengalami cita-cita intelektual. Permasalahan pokok yang dijadikan acuan dalam konsep ini pada dasarnya tidaklah terlalu jauh dari pandangan 'pemapanan' akan praktik-praktik pendidikan, pendek kata intelektualisme pendidikanpun tak terlepas dari subjek kepentingannya. Dua variasi dasar yang mewarnai intelektualisme pendidikan, yakni intelektualisme pendidikan teologis, yang lebih berorientasi pada karya teolog-teolog ternama. Sedangkan bentuk kedua yang bersifat sekuler lebih pada penekanan sekularitas dari hasil pemikirannya, utamanya persoalan tentang pendidikan itu sendiri. Satu hal yang perlu ditambahkan disini adalah penekanan paradigma intelektual ini masih terbelenggu seputar muatan yang tanpa sadar terpola dalam arus pemikiran seorang intelektualis itu sendiri.

c. Konservatisme Pendidikan

Konservatisme pada dasarnya adalah posisi mendukung ketaatan terhadap institusi atau lembagalembaga yang telah teruji oleh zaman, dan yang terpenting telah disepakati bersama dengan segala ketentuan mendasar yang terus ditaati.

Dalam dunia pendidikan agenda utama seorang konservatif adalah melestarikan pola sosial dan tradisi yang sudah ada. Pembagian ke dalam dua definitif, baik secara teologis maupun sekuler lebih pada penjelasan yang menitikberatkan pada aspek bagaimana cara seorang konservatif mempertahankan sebuah tatanan yang sudah ada, terlepas tatanan tersebut bernilai rancu atau bahkan tidak tepat sama sekali. Konservatisme lebih berkecenderungan menempatkan pada posisi yang aman, yang meskipun nantinya secara sadar atau tidak sadar justru kondisi yang sedang dijalaninya mengandung berbagai macam kejanggalan dan kerusakan kesadaran yang tidak dapat berkembang sama sekali. Bagaimana bisa kita mengasumsikan bahwa ritualisme kehidupan dengan berbagai macam atribut realitas yang dihasilkan dengan hanya dihadapi melalui konsep yang semata-mata lebih menitik beratkan pada aspek kemapanan yang sudah ada. 
Dengan demikian jangkauan einlightment masih sangat jauh dari seorang yang mempunyai keyakinan dan pendirian konservatif tanpa sadar terkooptasi pada kondisi yang terpolarisasi akan muatan-muatan yang telah dianutnya, tanpa berani sedikitpun untuk keluar dari tatanan itu sendiri.

Memaknai Paradigma Liberal

a. Liberalisme Pendidikan

Seorang liberal berpendapat bahwa tujuan utama pendidikan adalah untuk melestarikan dan memperbaiki tatanan sosial yang ada dengan cara mendidik secara efektif berdasarkan realitas sosial yang ada. Intensitas liberalisme pendidikan ini terdiri dari dua bagian pokok yang terbagi dalam liberalisme metodis (mempolakan) dan liberalisme yang berupa direktif (mengarahkan). Seorang liberalis sendiri pada dasarnya lebih menempatkan dirinya pada posisi 'menjaga' apa yang sudah ada, tanpa ada tahapan pemikiran dan kritisisasi secara bebas untuk keluar dalam lintasan tersebut. Kalaupun 'kebebasan' yang dimaksud hanya sebatas 'perbaikan' dari tatanan yang ada, bukannya secara berani menampilkan tatanan baru yang lebih didasari pada pikiran dan pemikiran bebas yang sesungguhnya. Seorang liberalis tidak mampu menjadikan dirinya penentu tatanan, sebab tingkat kesadaran yang dicapai baru sampai pada tahap kebebasan berekspresi bukannya kebebasan untuk bereksperimen. Terlepas dari pernyataan bahwa liberalisme pendidikan pada hakikatnya masih bagian dari 'polarisasi' muatan tatanan (pengetahuan) gaya baru tanpa menghilangkan esensi tujuan utamanya, yakni kooptasi kesadaran lewat ilmu dan pengetahuan sebagai hasil pembelajaran dari apa yang dinamakan pendidikan.

b. Liberasionisme Pendidikan

Liberasionisme bersudut pandang pada pelurusan terhadap sistem dan tatanan politik yang ada dengan segala konsekuensinya, jenis paradigma ini tentu saja sebagai bagian dari ekspresi kebebasan individu semaksimal mungkin. Bagi seorang liberasionisme, sekolah haruslah bersifat objektif (rasionalilmiah), namun tidak sentral. Dimana fungsi sekolah bukan hanya sebagai tempat cara berpikir efektif (rasional-ilmiah) melainkan juga mengenal kebijakan tertinggi atas sebuah program sosial konstruktif, dengan kata lain liberasionisme dilandasi oleh kebenaran secara terbuka. Variasi dalam paradigma liberasionisme itu sendiri terbagi dalam dua bagian, yaitu liberasionisme pembaharuan yang lebih konservatif sifatnya. Sedangkan pada kondisi yang kedua, yakni liberasionisme revolusioner yang lebih condong ke arah radikalisme secara kritis atas sistem tatanan politik yang ada. Pada konteks liberasionisme yang terakhir lebih pada kemerdekaan individu menentukan kebijakan atas tatanan yang sudah tersistem yang semata-mata dianggap tidak memenuhi hakikat kebaikan yang disetujui bersama. Paradigma yang terakhir ini sudah mulai menghampiri nilai kesadaran yang dulunya terbelenggu oleh labirin-labirin 'struktur' dan' sistem' pendidikan yang ada, yang menarik adalah ketika tahapan ini mampu menembus batas kesadaran yang selama ini membelenggu nilai kesadaran 'pelaku' pengkonsumsi tatanan yang berbentuk ilmu dan pengetahuan melalui pendidikan. Dengan demikian tahapan selanjutnya lebih radikal tanpa mengenal pemakaian tatanan ilmu dan pengetahuan yang dianggap tidak mempunyai daya tawar (bargaining) dalam menghadapi bentuk realitas yang semakin kompleks, yang kemudian terinspirasi guna membentuk sebuah komunitas yang tercerahkan. Kondisi terakhir ini nantinya apa yang dinamakan anarkisme pendidikan.

c. Anarkisme Pendidikan

Hal yang paling mendasar yang ingin dicapai oleh seorang anarkisme pendidikan adalah menekankan minimalisasi dan atau menghapuskan pembatasan kelembagaan-kelembagaan terhadap perilaku personal, sejauh mana kita mampu mendeinstitusionalkan masyarakat-membuat masyarakat bebas lembaga dengan berbagai pertimbangan yang telah dilembagakan sendiri. Dimana keyakinan akan perombakan humanistik berskala besar sangat dimungkinkan disana dengan cara penghapusan institusi atau lembaga resmi yang dinilai tidak relevan, bahkan cenderung merugikan. Variasi dari anarkisme pendidikan ini terbagi dalam dua pembedaan pokok, yaitu ; Pertama anarkisme taktis, dimana penekanan akan kepentingan sosial masyarakat lebih didahulukan, dalam artian 'sentuhan' secara langsung atas realitas sosial lebih dinilai bernilai guna dari pada penggunaan administratif oleh institusi atau lembaga yang selama ini justru dinilai tidak menyentuh dan bernilai guna. Kedua anarkisme utopis, yang memimpikan masyarakat 'permanen' terbebaskan dari institusi kelembagaan yang menyesatkan. Apa yang menjadi dasar dari paradigma pendidikan yang terakhir ini pada hakikatnya memberikan serta memperkenalkan ruang baru bagi pembentukan kesadaran individu dalam menghadapi permasalahan kehidupan. Selama ini institusi atau lembaga lewat pendidikan dengan menelorkan apa yang kemudian dinamakan ilmu dan pengetahuan tidak mampu mengkondisikan dirinya pada posisi sebagai subjek realitas, justru pendidikan menjadikan individu tersebut terikat menjadi tawanan (objek) dari sebuah bentuk kesadaran. Individu tidak diberi ruang untuk memilih dan cenderung secara tidak sadar masuk dalam lingkaran polarisasi kesadaran tingkat tinggi.

Anarkisme pendidikan lebih pada sebuah bentuk konsepsi pemikiran bagaimana cara merasionalisasikan pendidikan, meskipun paradigma ini cenderung menolak secara tegas dari tatanan 
yang sudah ada. Dialektisasi dari paradigma-paradigma sebelumnya yang dinilai belum mampu mewakili seluruh kepentingan dan bahkan merepresentasikan sebuah 'hegemony ideology' diluar batas kewenangan yang ada, dengan mempolakan setiap bentuk kesadaran yang ada.

Dengan demikian setidaknya dalam tahapan terakhir ini sebagai material dasar terbentuknya kesadaran kritis yang lebih mengarah ke bentuk "rasionalisasi pendidikan" dengan berbagai pemasukan kesadaran kritis dan bebas menafsirkan segala bentuk realitas tanpa ada polarisasi kesadaran yang menyesatkan. Jenis perbincangan yang terakhir dalam bahasa Habermas disebut dengan 'critical conciousness' dimana penekanan pada bentuk pemikiran yang lebih rasional-ilmiah (praktis) diperoleh di dalamnya.

\section{Analisa sebagai "Sebuah Refleksi Kritis"}

Pendidikan mempunyai banyak implikasi dan selalu mengikuti aturan sistem yang telah ditetapkan melalui sebuah struktur hirarkis diatasnya. Negara atau pihak yang berkuasa untuk membentuk dengan proses ke bawah, serangkaian klaim bahwa proses tersebut secara riil mewakili hasrat untuk mendirikan bangunan yang "tercerahkan".

Sekolah primer kuno dalam pandangan Gramsci (2000: 177) menempati bangunan terpisah yang di dalamnya terdapat dua elemen. Pertama, mengacu pada materi-materi esensial mengenai ilmu pengetahuan alam. Rasa ketertarikan pada alam dan segenap kemajuan yang harus mendapatkan prioritas disamping sisi lain dari realitas. Transformasi nilai empirisme dan saintis dunia Barat yang masuk ke Indonesia bukanlah melalui berbagai tahapan unik dan klasifikasi penemuan-penemuan, inovasi-inovasi mandiri yang benar-benar selalu mengikuti gerakan alam. Indonesia dalam skema besar pengetahuan alam dunia hanya mendapatkan dan harus mengakui dirinya sebagai "anak bawang" peradaban yang ditentukan oleh kualitas pendidikan. Pengaruh Barat yang dominan seakan-akan menumbuhkan keterpurukan pra-konfirmasi dan harus menjatuhkan derajat sebagai manusia dan bangsa yang benar-benar terdidik oleh alam. Lebih lanjut penemuan dalam berbagai bidang masih mengimpor dalam berbagai macam kemasan. Konsumerisme pengetahuan yang melanda Indonesia sebagai gaya dan primitivisasi yang terpola. Akhirnya harus bermuara pada ketidakberdayaan dan marginalisasi kemampuan intelektual. Pelajaran Kedua, adalah gagasan tentang hak-hak dan kewajiban sipil. Artinya, setiap individu harus memilih kalau tidak mau terjebak dalam polarisasi pendidikan yang dipolitisir sedemikian rupa menjadi sebuah ideologi. Gagasan ilmiah dimaksudkan untuk melibatkan murid memasuki soceitas rerum dunia benda-benda, sedangkan gagasan tentang hak dan kewajiban sipil bermaksud mengajak untuk masuk ke dalam koridor negara serta peranannya menjadi masyarakat sipil.

Gejala keterpurukan tujuan yang berawal dari ambiguitas konsepsinya, dapat dilihat secara mendalam pada kemampuan orang-orang terdidik dalam berkreasi. Sebagian besar fasilitas dan piranti pendukung dari fenomena Indonesia adalah fatamorgana. Pola dasar yang diterapkan mengacu pada adopsi bukan adaptasi. Kelangkaan konjungtur untuk menarik, dalam rangka transfer pengetahuan tidak benar-benar bersintesa, namun kenyataannya justru semakin membuat kreativitas sumber daya manusia Indonesia mandeg.

Iklim pendidikan yang tersudut pada satu ideologi bisa membawa konsekuensi logis adanya monopoli sistem pengetahuan dan akibatnya menutup saluran lain yang seharusnya bersama-sama mengembangkan sikap kedewasaan berpikir dan berkreasi. Rangsangan dari luar yang masuk akibat globalisasi menempati peranan besar dari usaha melepas tradisi lama dan menciptakan tradisi baru yang merupakan hasil seleksi ketat.

Perubahan budaya pendidikan dari lama ke baru tidak akan berjalan lancar dan benar-benar berhasil kalau tidak melewati proses "kritisisme". Bangunan besar ideologi pendidikan adalah kategori rasional dalam memahami kehendak pendidikan itu sendiri. Hukum negara lebih bernuansa politis daripada pembagian yang merata yang menentukan porsi yang sama besarnya bagi hidup dan berkembangnya lembaga-lembaga pendidikan. Hukum negara terbukti sangat subjektif memandang jatah pendidikan sehingga dapat dikatakan itu sebagai "tirani pendidikan" padahal sebenarnya hukum juga hasil produk kegiatan manusia. Secara politis barang tentu kekuasaan yang ada pada negara akan dipegang melalui hasil pemilu. Golongan yang memerintah dapat dengan mudah membunuh satu aliran pendidikan ketimbang mencoba mengupayakan perbaikan menyeluruh.

Terminologi "instruksi" pendidikan adalah penebar jaring monopoli aliran. Usaha-usaha rasionalisasi lembaga pendidikan tidak akan terwujud pada perkembangan terakhir kalau mainstream kebijakan negara masih harus ditaati. Kurikulumisasi ketat mungkin hanya ada di lingkungan sekolah formal milik negara saja. Sedangkan lembaga-lembaga pendidikan swasta akan terkooptasi oleh institusi pemerintah dan kolese-kolese mempunyai cara tersendiri untuk menyegarkan aliran, karena ideologi pendidikannya yang benar-benar separuh bebas dari instruksi negara.

Priyayi dan historisitasnya adalah elemen yang menjadi pioner, pemegang terbanyak dari tradisi pendidikan Barat. Perumusan rasionalisasi Weberian harus mengalami keadaan surutnya ketika perang 
dunia kedua berakhir. Indonesia pada era berdirinya memang mendambakan suatu jenis pendidikan ekletik, bernuansa semi-modern namun dengan dasar konservatif. Radikalisme pendidikan masih terlalu jauh dalam bayangan kita saat ini. Kemarahan, keputusasaan dan ketidakpuasan menjadi pemantik dalam proses enlightment pendidikan yang telah memiliki modal dasar tersebut. Modal awal, dengan kejatuhan harga bangsawan karena masuknya demokrasi dari konsep Barat sebenarnya merupakan momen penting yang harus mendapatkan analisa lebih. Gambaran keadaan pendidikan yang belum dewasa tapi mempunyai landasan cukup relevan bagi pembentukan konsep baru yang tidak harus terjebak dalam sekat-sekat ideologi pendidikan yang tegas.

Lombard (2000: 167) mengamati bahwa garis hirarki priyayi sangat rumit dalam hubungannya dengan proses transformasi konsep-konsep dari Barat. Selanjutnya perkembangan bagus dapat dicapai golongan ini karena universitas banyak berdiri. Adanya daya tarik dominan untuk menaikkan prestise akhirnya berhasil membuka kedok bahwa pendidikan awal Indonesia adalah konservatif yang mengarah pada selera kaum aristokrat. Seperti diungkap Gramsci lebih lanjut mengenai peranan pembentukan "aturan main" antara pendidikan dan negara akan menghasilkan hubungan resiprok diantara mereka sehingga kedudukan masyarakat lain dalam pendidikan tidak sama.

Belajar bukanlah merupakan persoalan kerja ansich. Belajar adalah proses pembentukan sudut pandang dalam menilai dan merubah realitas. Dialog antara "diri" dan lingkungannya tercermin dalam perkenalan seorang anak 17 tahun dengan penjara struktur pendidikannya. Ketika dia mulai sadar bahwa selama ini apa yang diberikan oleh lingkungan formalnya bukanlah pendidikan dalam arti yang sebenarnya. Kontraksi yang membuat dan seringkali menimpa kebiasaan konservatif, dimulai dari tertutupnya wawasan mengenai zaman. Sebuah kondisi dengan kepekaan kurang terhadap perubahan zaman. Munculnya pendidikan liberal dimulai pada kurun setelah tirani pendidikan mulai dipertanyakan keabsahannya. Bayangan yang dikemukakan oleh liberalisme adalah mencetak seorang manusia dengan kompleksitas spesialisasi yang diharapkan dapat memainkan peran penting untuk melihat dan merubah realitas. Orientasinya kedepan, diselubungi kepentingan untuk meneruskan ide-ide individualistik. Kalau itu yang dinamakan konsep pendidikan yang baik, maka kita harus membenturkannya dengan kenyatan sosial. Altruisme dapat merasuk dalam setiap wawasan liberalisme dengan kesungguhan dan keterbukaan terbatas. Persoalannya dapat semakin meruncing menjadi sebuah konflik apabila terjadi salah pengertian, rasa penat dan bosan karena kekuasaan pengetahuan hanya berada dalam genggaman satu person atau golongan tertentu yang eksklusif.

Indonesia adalah reperesentasi sebuah bangsa yang sulit beradaptasi atau memberikan senyawa dari unsur pengetahuan yang masuk lalu merumuskan sebuah landasan bersama yang merangkum banyak pendapat dan memberikan solusi. Kelangsungan pendidikan yang pincang ini memaksa para elemen pendidikan mulai merasakan adanya sebuah tanggung jawab yang dirumuskan secara cepat. Indonesia sudah mempunyai landasan untuk memilih. Konservatif atau liberalis mempunyai gaya dan arah sendiri yang selama berdirinya Indonesia selalu masuk dalam lingkaran birokrasi, manajemen negara yang semakin membuang keunikan masing-masing ideologi pendidikan tersebut.

Pengejahwantahan ideologi pendidikan selalu berbenturan dengan negara karena dunia pendidikan belum dapat berdiri dipihak lain yang lebih relevan untuk mengembangkan dirinya sendiri. Ketergantungan pada negara sebagai suplier terbanyak untuk menunjang gagasan seputar pemeratan pengetahuan dengan tujuan mendapat hasil instan, berupa sarjana dan pekerja terampil siap pakai yang diterjunkan dalam berbagai lapangan pekerjaan. Terjadinya missing link di dunia pendidikan mengacu pada penentuan konsep yang kabur disamping kesalahan mengambil keputusan untuk bekerjasama sebagai bagian dari masyarakat sipil. Negara dengan sentralisasi wewenang akhirnya berhasil membuat dunia pendidikan benar-benar menjadi barang mati yang harus rela ditendang kesana-kemari dan di goyang oleh berbagai kepentingan yang memang bukan seharusnya terjadi dan menjadi kehendaknya (Sudarsana, 2015).

Rantai penghubung antara dunia pendidikan dengan kehidupan, realitas adalah terletak pada konsepsi yang utuh. Ideologi pendidikan sebagai klaim hanya melihat realitas separuhnya saja sesuai dengan kemampuan teleologis yang melandasinya. Lebih jauh, dinamika konseptual sendiri harus selalu berubah secara pragmatis mengikuti alur baru yang selalu berubah sebagai hasil interaksi antara zaman kini dengan yang lalu menjadi terjembatani.

Pandangan Durkheim mengenai perubahan sosial, menempatkan historisitas sebagai salah satu dari dua aspek pentingnya. Kilasbalik (flashback) dapat dilukiskan sebagai salah satu upaya instrospeksi dan rekonstruksi, mengumpulkan serpihan-serpihan dan pembelajaran serius untuk menghindari missing link dikemudian waktu. 


\section{Sebuah Konstruksi Paradigma Baru Pendidikan}

Nilai akan sebuah kesadaran dalam berpikir dan menentukan pilihan memerlukan prasyarat khusus guna memasuki sebuah wilayah yang tercipta dari konstruksi pemikiran sebagai hasil dialektika pemikiran-pemikiran yang sudah ada sebelumnya. Satu hal yang perlu disepakati bersama disini adalah kondisi akan nilai kesadaran yang selama ini katakanlah terbelenggu oleh berbagai macam 'kepentingan' melalui jalur pendidikan. Bisa ditebak langkah selanjutnya, dimana pendidikan yang notabene sebagai gudang penyuplai ilmu dan pengetahuan digunakan sebagai ajang 'hegemonic ideology' dengan membatasi segala bentuk pemikiran yang bersifat bebas dan kritis. Konsep pola pembentukan semacam itu sangatlah berbahaya bagi sebuah generasi yang tanpa sadar pola pemikirannya terbentuk guna memenuhi kepentingan sebagian kelompok. Perjalanan tiap wacana yang dijalankan, baik itu dimulai dari paradigma pendidikan yang bersifat konservatif dengan berbagai macam hasil sekresi tidak dapat memberikan peluang sama sekali bagi individu untuk menuju sebuah pencerahan pemikiran. Bahkan tidak menutup kemungkinan pada topik paradigma yang satu ini jelas-jelas menciptakan sebuah survivalisme kapital yang berlebihan, dengan menyebarkan pola-pola yang menjadikan individu sulit bertindak sebagai subjek ketika menerima pengetahuan lewat pendidikan. Dimana seolah-olah pendidikan merepresentasikan bentuk penyadaran yang penuh dengan kebajikan dan membuat kehidupan manusia menjadi lebih baik dalam menghadapi tantangan kehidupannya. Paradigma yang kedua dengan menekankan kata 'liberal' yang secara umum merepresentasikan kebebasan dalam segala bentuk pemikiran akan tetapi tetap terpaku dalam koridor yang telah ditata sebelumnya dan tidak berani meninggalkan secara langsung tatanan kesadaran tersebut, bahkan cenderung melestarikannya.

Paradigma Kritis Untuk Pendidikan di Indonesia; Menilik dari pembukaan Undang-undang Dasar 1945 yang berbunyi “... turut mencerdaskan kehidupan bangsa dan ikut melaksanakan ketertiban dunia ...". Jelas sudah bahwa ada kesepakatan luhur yang seharusnya dijadikan dasar dan patokan utama dalam menentukan kebijakan yang berkaitan dengan segala hal-ikhwal pendidikan, khususnya pendidikan di Indonesia. Ukuran maju-tidaknya sebuah bangsa tolok ukurnya bisa dilihat dari kualitas pendidikan bangsa tersebut, artinya makin maju tingkat pendidikan sebuah bangsa maka secara tidak langsung maju pula negara tersebut. Mengapa? karena dengan meningkatnya kualitas pendidikan akan berdampak pada peningkatan kualitas sumber daya manusianya pula. Dengan demikian tidak sulit sebenarnya untuk menjadikan sebuah bangsa cerdas dan berkesadaran yang tinggi. Akan tetapi ternyata tidaklah semudah yang dikira, karena berbagai macam pertimbangan secara intern sebagai pembuat dan pelaku kebijakan (birokrasi pemerintahan) sebagai penentu nilai kebijakan untuk pendidikan. Belum lagi permasalahan 'muatan' pendidikan itu sendiri yang sarat dengan nilai kepentingan, dimana pendidikan itu sendiri tidak bisa lepas dari ideologi serta paradigma apa yang hendak dipakai dan dicapai dalam pembentukan pola.

Solusi baru yang mempunyai tujuan ganda adalah memasukkan nilai kritisisme yang pantangan dari kebiasaan rutin dalam iklim ruangan kelas. Pemilahan ini bukan hal yang mudah dilakukan, mengingat budaya patron-klien masih tetap dirapatkan fungsinya. Konservativisme maupun liberalisme merupakan modal, dalam artian selama ini keberadaannya belum menyentuh arah dan konsepsi lanjut mengenai eksistensi pendidikan. Sedangkan pengakuan atas ideologi dari salah satunya juga merupakan proyek spekulatif yang mendorong timbulnya ketegangan baru yang mungkin diperparah oleh konflik dalam rumusan pendidikan selanjutnya.

\section{KESIMPULAN}

Selama ini pemahaman masyarakat berkenaan dengan pendidikan adalah memposisikan pendidikan sebagai satu-satunya bentuk perolehan ilmu dan pengetahuan yang ada. Terlepas itu nantinya terpatok pada persoalan pendidikan yang cenderung melembaga atau persoalan hakikat pendidikan itu sendiri.

Berbagai macam bentuk kesadaran yang telah tercipta dari rahim pendidikan tidak lebih hanyalah sebagai bentuk penjajahan otoritas kesadaran itu sendiri. Dimulai dari bentuk pendidikan yang cenderung konservatif, dengan menitik-beratkan pada harmonisasi kesadaran yang telah terpolakan sebelumnya dengan tidak menyadari sama sekali berbagai kepentingan idelogi lewat pendidikan bergentayangan di dalamnya. Bentukan paradigma pendidikan yang kedua yang kemudian dinamakan liberalisme pendidikan tidak lebih hanyalah kelanjutan dari konsep pembentukan pola kesadaran gaya baru yang notabene tidak jauh dari faktor kepentingan ideologi juga. Namun satu hal yang pasti dan perlu kita sepakati disini adalah perlunya kita melakukan konsolidasi kesadaran menuju kecerahan dalam berpikir.

Wacana paradigma pendidikan yang dinamakan anarkisme pendidikan merupakan rumusan baru dalam pencapaian pencerahan dalam proses berpikir menuju arah kesadaran yang sebenarnya. Terakhir bahwa pendidikan pada dasarnya sebagai pemberi seperangkat gagasan serta ide yang memungkinkan di dalamnya membentuk kesadaran dalam berpikir. Terlebih pada persoalan sejauh mana pendidikan menjadi sebuah alternatif pilihan dalam pencapaian ilmu dan pengetahuan yang didapat. 


\section{DAFTAR PUSTAKA}

Barnadib, I. (1987). Filsafat Pendidikan Sistem Dan Metode. Yogyakarta: Penerbit Andi.

Boyer, E. L. (2000). Civic education for responsible citizen. Educational Leadership, 48-Nov, 4-9.

Dodd, C. H. (1998). Dynamics of Intercultural Communication (Tifth Edition). New York: McGraw-Hill.

Educational for Democracy Project. (2002). Education for democracy. American Federation of Teachers, $313(5), 57-62$.

Fadjar, A. M. (2004). Holistika Pemikiran Pendidikan. Jakarta: Radja Grafindo Persada.

Freire, P. (1999). Politik Pendidikan; Kebudayaan, Kekuasaan, dan Pembebasan. . Yogyakarta: Pustaka Pelajar

Gramsci, A. (2000). Sejarah dan Budaya. Surabaya: Pustaka Promothea

Illich, I. (2000). Bebaskan Masyarakat Dari Belenggu Sekolah. Jakarta: Yayasan Obor Indonesia.

Lombard, D. (2000). Nusa Jawa: Silang Budaya, Jilid I. . Jakarta: Gramedia.

Meilani Hartono. (2017). Analisis Kebutuhan dalam Pengembangan Model Pendidikan Multikultur Transsformatif dalam Pembelajaran PPKn dan IPS di Sekolah Dasar. Journal of Education Research and Evaluation. Vol.1 (3) pp. 192-197

Schement, J. R. (2002). Encyclopedia of Cpmmunication and Information (Volume 1). New York: McMilland Reference.

Sharon Lee. (1994). Social Studies in a Global Society. America, Canada: Delmar Publishing Inc.

Shaver, J. P. (1991). Handbook of research on social studies teaching and learning. New York, NY: McMilland Publishing Company.

Sudarsana, I. K. (2015). Peningkatan Mutu Pendidikan Luar Sekolah Dalam Upaya Pembangunan Sumber Daya Manusia. Jurnal Penjaminan Mutu, (Volume 1 Nomor 1 Pebruari 2015), 1-14.

Sudarsana, I. K. (2016). Pemikiran Tokoh Pendidikan Dalam Buku Lifelong Learning: Policies, Practices, And Programs (Perspektif Peningkatan Mutu Pendidikan di Indonesia). Jurnal Penjaminan Mutu, (2016), 44-53.

Suriasumantri, J. (1996). Filsafat Ilmu; Sebuah Pengantar Populer. Jakarta: Sinar Harapan.

Suriasumantri, J. (1994). Ilmu Dalam Perspektif. Jakarta: Yayasan Obor Indonesia.

Ting-Toomey, S. (1999). Communicating Across Cultures. New York: The Guilford Prublications, Inc.

UNESCO. (1999). Education for international understanding and peace in Asia and the Fasific. Ichon \& Kyongju: Korean National Commission for UNESCO.

Weber, M. (2000). Etika Protestan dan Semangat Kapitalisme. Surabaya: Pustaka Promothea. 